\title{
Severe neurological consequences of subclavian steal in the setting of cardiogenic shock
}

\author{
Sara Hefton, ${ }^{1}$ Nikolay Bogush, ${ }^{2}$ Robert S Crawford, ${ }^{3}$ Robert M Reed ${ }^{4}$
}

${ }^{1}$ Department of Neurology, University of Maryland Medical Center, Baltimore, Maryland, USA

${ }^{2}$ University of Maryland Baltimore, Maryland, USA ${ }^{3}$ Department of Vascular Surgery \& Anesthesiology, University of Maryland, Baltimore, Maryland, USA

${ }^{4}$ Department of Pulmonary and Critical Care Medicine University of Maryland, Baltimore, Maryland, USA

\section{Correspondence to} Dr Robert Michael Reed, rreed@medicine.umaryland.edu

Accepted 24 June 2015

CrossMark

\section{To cite: Hefton $S$,} Bogush N, Crawford RS, et al. BMJ Case Rep Published online: [please include Day Month Year] doi:10.1136/bcr-2015210274

\section{DESCRIPTION}

A woman in her 70s was found lying prone, with an ST-elevation myocardial infarction and in cardiogenic shock. She was obtunded, answering 'No' to all questions, and was observed to have anisocoria with a pinpoint right pupil, $5 \mathrm{~mm}$ left pupil, decreased right corneal reflex and nystagmus. Head CT scan was unremarkable, but CT angiogram of the chest demonstrated an occluded left subclavian with reconstitution proximal to the left vertebral artery origin (figure 1 and video 1). Her neurological deficits were thought to be attributable to reduced cardiac perfusion of a cerebral circulation made tenuous by subclavian steal physiology.

Subclavian steal syndrome occurs when proximal stenosis or occlusion of the subclavian artery
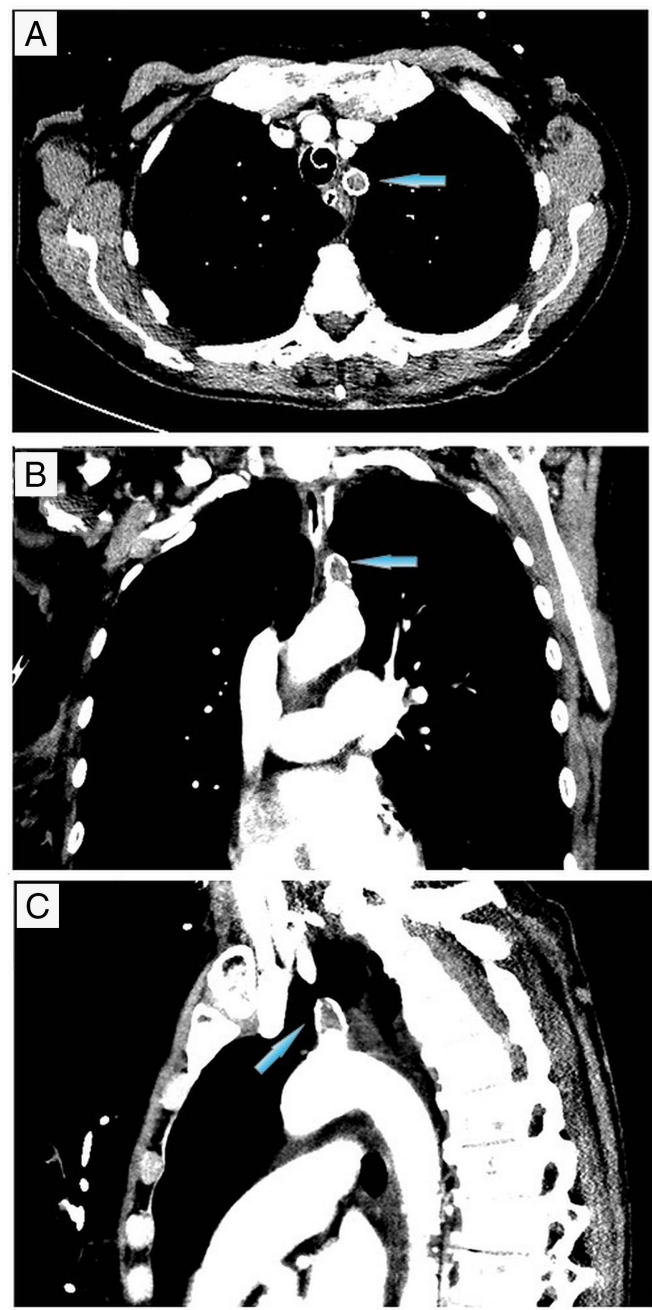

Figure $1 \mathrm{CT}$ angiography demonstrating calcification and occlusion of proximal left subclavian artery (blue arrow) at its origin with reconstitution prior to vertebral artery origin. Axial (A), coronal (B) and sagittal (C) views presented.

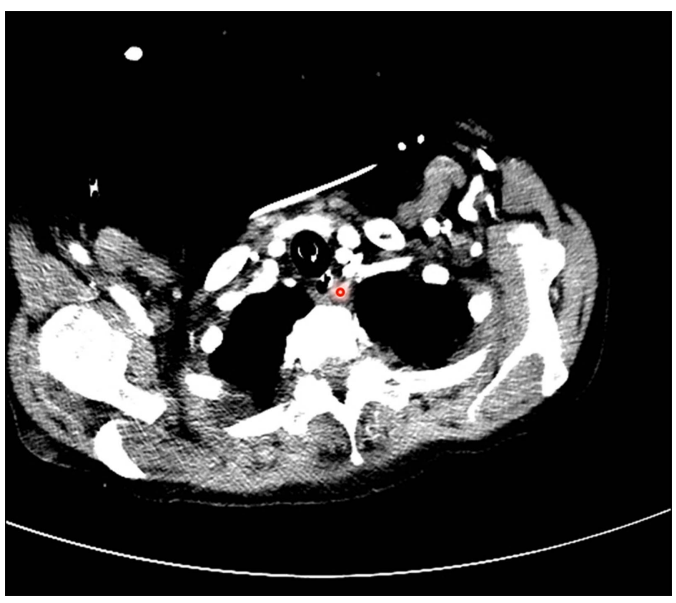

Video 1 CT images reviewed.

decreases flow and pressure beyond the point of obstruction. This causes retrograde flow in the ipsilateral vertebral artery. ${ }^{1}$ In partial steal, flow remains antegrade in diastole but becomes retrograde during systole, and in complete steal, flow remains retrograde throughout the cardiac cycle. ${ }^{2}$ It is typically caused by atherosclerosis, and prevalence estimates range between $0.6 \%$ and $6.4 \% .^{3}$ Most cases are left-sided and benign, with symptoms occurring in only $7.4 \%$ of patients in one series. ${ }^{2}$ Symptoms result from ischaemia and may be neurological in vertebrobasilar ischaemia (vertigo, diplopia, ataxia, drop attacks), musculoskeletal in limb ischaemia (claudication, paraesthesias, weakness) or cardiac in the setting of retrograde graft blood flow after coronary artery bypass grafts from left internal mammary artery (angina, arrhythmias). ${ }^{3}$ A common physical finding is that of a $>20 \mathrm{~mm} \mathrm{Hg}$ blood pressure difference between limbs. $^{23}$ Treatment is typically medical, but symptomatic cases may be treated surgically or endovascularly. ${ }^{1}$

\section{Learning points}

Subclavian steal can result in vertebrobasilar ischaemia.

- Most cases of subclavian steal are asymptomatic and do not require more than medical intervention to optimise atherosclerosis risk factors.

- As large areas of the brain are dependent on tenuous collateral circulation in subclavian steal, the neurological consequences of impaired circulation may be severe.

Patient consent Not obtained. 


\section{Images in...}

Provenance and peer review Not commissioned; externally peer reviewed.

\section{REFERENCES}

1 Potter BJ, Pinto DS. Subclavian steal syndrome. Circulation 2014;129:2320-3.
2 Labropoulos N, Nandivada P, Bekelis K. Prevalence and impact of the subclavian steal syndrome. Ann Surg 2010;252:166-70.

3 Osiro S, Zurada A, Gielecki J, et al. A review of subclavian steal syndrome with clinical correlation. Med Sci Monit 2012;18:RA57-63.

Copyright 2015 BMJ Publishing Group. All rights reserved. For permission to reuse any of this content visit http://group.bmj.com/group/rights-licensing/permissions.

BMJ Case Report Fellows may re-use this article for personal use and teaching without any further permission.

Become a Fellow of BMJ Case Reports today and you can:

- Submit as many cases as you like

- Enjoy fast sympathetic peer review and rapid publication of accepted articles

- Access all the published articles

- Re-use any of the published material for personal use and teaching without further permission

For information on Institutional Fellowships contact consortiasales@bmjgroup.com

Visit casereports.bmj.com for more articles like this and to become a Fellow 